have rarely seen a case of ordinary valvular disease, either aortic or mitral, in which great beuefit has not followed the administration of digitalis ; in the cases before us it signally failed to improve the symptoms; indeed, it seemed rather to aggravate them. I have sometimes thought that it may have been from the observation of such cases that the very curious doctrine, still, I believe, taught by some, of the dangers of digitalis in aortic disease came into existence.

In conclusion, I have to thank the physicians to the infirmary for their great kindness in permitting me to make use of the cases.

ERRATUM.-In the former part of this article, published last week, the word "ectatic" is twice wrongly printed "ecstatic."

\section{ON PSORIASIS FROM BORAX.} BY W. R. GOWERS, M.D., F.R.C.P.

Among the cutıneous eruptions which may result from the administration of drugs, psoriasis has not, I think, been hitherto included. The following facts show that an eruption of characteristic psoriasis may result from the internal administration of borax. The facts have been met with in the use of borax in the treatment of obstinate cases of epilepsy, in which bromide fails. The first instance was in the case of a man who had taken borax for nearly two years in doses of first fifteen grains and then a scruple three times daily. An eruption of psoriasis made its appearance on bis limbs and trunk, developing to a considerable extent in the course of a few weeks. Five minims of arsenical solution were added to each dose of borax, and the eruption rapidly disappeared. Shortly afterwards Dr. Spencer of Clifton, in mentioning to me a case of epilepsy in which he had given borax with advantage, inquired if $I$ had met with any inconveniences from its use. I told him of this case, in which I thought it possible that the psoriasis was produced by the borax, and he informed me that in his patient the same eruption had just appeared. In this case also the rash rapidly cleared away under the influence of arsenic, and a few weeks later Dr. Spencer wrote to me, "I have not the slightest doubt that the borax caused the psoriasis, or that the arsenic cured it." A third instance has lately come under my notice. The patient was a young man who had suffered from epilepsy since infancy, and was always rendered worse by bromide, so that he was brought to me with the request that bromide might on no account be given. $\mathrm{He}$ took borax, first fifteen graius and then a scruple turee times a day, with greater benefit than had resulted from any previous treatment, and after eight months an eruption of psoriasis appeared. Arsenic was added, but the result of treatment has not yet been ascertained.

The eraption in these cases occurred on the trunk, arms, and legs, but more on the arms than elsewhere. The face was free. It was located on both the flexor and extensor aspects. The patches varied in size, up to an inch and a half in diameter. Their appearance was quite characteristic, but the scales were not so thick as they sometimes are in ordinary psoriasis. In no case was there a histury of syphilis, and in Dr. Spencer's patient syphilis could, with certainty, be excluded.

Presentations. -Last week Dr. Richard Budd, Physician to the North Devon Infiimary, was presented by Earl Fortescue, on behalf of the citizens of Barnstaple and many other friends in the county of $D$ evon, with a portrait of himself and a cheque for $\$ 400$. The testimoulal was given in acknowledgmeut of the long and valuable services rendered by Dr. Budd to the infirmary, and also as a mark of the personal esteem in which be is held by the donors. In returning thanks, Dr. Budd hinted at his resolve to devote the sum he had recelved to the carrying out at a future time of a plan which had long occupied his thought viz., the erection of a detached building for the work of the out-patient department. - A case of surglcal instruments has been presented to Mr. A. O. H. Philips, L.R.C.P. Lond., by the merlical practitioners resident in Swansea, on the occasion of his leaving that town for Australia.

\section{atettirtor}

\section{HOSPITAL PRAOTICE, BRITISH AND FOREIGN.}

Nulla autem est alia pro certo noscendi via, nisi quamplurimas et morborum et disscetionum historias, tum aliorum tum proprias collectas habere, et inter se compurare.-Morgagni De Sed. et Caus. Morb., lib. iv. Procmium.

\section{GUY'S HOSPITAL.}

INNOMINATE ANEURISM ; LIGATURE OF LEFT CAROTID; ARTERITIS DEFORMANS OF AORTA; CEDEMA AND GANGRENE OF THE LEFT LUNG ; DEATH.

\section{(Under the care of Mr. BRYANT.)}

For the notes of this case we are indebted to Mr. Morris. Alfred T_, aged forty, was admitted into Job ward on March 17th, 1880. He belonged to the horse artillery, and had been in India. Nine months before admission he had rheumatism, and had severe pain in the right shoulder after. A month before he entered the hospital he first noticed a swelling which became painful, especially when he coughed. There was no history of syphilis.

On adınission, there was a large pulsating swelling extending from the middle of the right clavicle to about the inner fourth of the left, upwards as far as the thyroid carti. lage, and downwards as far as the third rib. The larynx was lying far to the left, causing irritation and much coughing. He could not swallow anything hard. The right pulse was weaker than the left. The chest was normally resonant; the heart sounds were normal, and the pupils equal. Pulsation could be felt in the tumour and extending in both posterior and anterior triangles from the trapezius down to the lower border of the second rib, and very slightly to the level of the third rib. Transversely, the pulsating swelling mea:ured $3 \frac{3}{4}$ in. ; from posterior border of one sternomastoid to the other $8 \frac{1}{2} \mathrm{in}$. ; the circumference of neck over most prominent part was $18 \frac{1}{4}$ in. The external jugular vein was distended, as were the veins in the base of the posterior triangle. The veins of the arm were also slightly full. There appeared to be no difference in the radial arteries. Just above the tumour the carotid could be felt pulsating, and pressure on this caused the pulsations in the tumour to fall from 80 to 72. This only lasted for one-sixth of a minute, the pulsations were then increased.

On March 26th, at 11 A.M., under chloroform, the left common carutid, which was felt to pulsate near the posterior border of the sterno-mastoid, was ligatured. The incision was made external to a greatly distended external jugular vem, the muscle was turned up, and the internal jugular vein was compressed. One or two large veins were divided, and considerable hæmorrhage took place; but these were presently secured with silk ligatures. The nerve was seen, and raised from the artery, and the artery was then secured with a catgut ligature. At 6 P.M. the patient was quiet; he had no pain, but complained of pressure on the windpipe, and of the apparent accumulation of phlegm. Pulse 100, temperature $97^{\circ}$. The local chardcter of the swelling was unaitered. On the 27 th there was no alteration in the swelling. The patient had a bad night. On the 28 th the pain in the shoulder had entirely subsided, but the pulsating surface had in no way decreased. On the 29th a choking seasation prevented sleep. The point of greatest prominence appeared to have advanced upwards, and on the following day the patient was in great distress, and could not speak above a whisper. There was severe pain over the left intercostal spaces, and the arr did not easily enter the left luog.

Un April 2nd the diet consisted of arrowront, beef-tea, milk, moistened toast (at times), and an enema was given every two hours containing abuut two minims of tincture of opium. On the loth there was a good deal of cedema around the aneurism, and the veins were rather prominent. Next day the tumour bad very greatly increased in prominence. The skin was of a deep, dusky red, and extended all round the rest of the neck, and over the most prominent part was a bulla containiug a dark fluid, in which was seen a wave movemeut with each pulsation. Over the surface were 